Олійник О. О., к.е.н., доцент, Пожарський Д. С., студент,

Торяник Т. В., студентка (Національний університет водного господарства та природокористування, м. Рівне)

\title{
МІГРАЦІЙНІ ОРІЄНТИРИ НАСЕЛЕННЯ ТРАНСКОРДОННИХ РЕГІОНІВ УКРАЇНИ: ГЕНДЕРНИЙ АСПЕКТ
}

\section{В статті досліджено міграційні настрої населення транскордонних регіонів України. Проаналізовано фактори вибору країни для тру- дової міграції, бажані країни для працевлаштування за кордоном, термін перебування. Визначено основні причини, які змушу- ють/змусили б шукати роботу за кордоном. \\ Ключові слова: гендер, міграція, працевлаштування, оплата праці, умови праці, населення.}

Постановка проблеми. Сьогодні проблематика трудової міграції досить гостро стоїть для України. Цьому сприяють зокрема сучасні трансформації в економічному, політичному, суспільному житті, зовнішні ризики. Так, станом на кінець 2018 року за кордоном, за даними Міністерства соціальної політики, працювали 3,2 мільйона українців [1]. Водночас за даними Міжнародної організації з міграції стверджують, що 12\% українців знайшли закордонну зайнятість або мають це в планах. Довгострокова перспектива також викликає занепокоєння: ООН вбачає зменшення кількості населення до 36,4 мільйона до 2050 року [2]. Посилює також проблему й трансформація гендерно-вікової структури української міграції, яка характеризується зростанням чисельності жінок-мігрантів (більш уразливої категорії мігрантів), зниженням середнього віку мігрантів, що провокує проблеми старіння нації, зниженням рівня народжуваності, погіршенням трудового потенціалу населення тощо [3]. За таких умов виникає необхідність в дослідженні гендерних особливостей міграційних настроїв населення задля формування ефективних гендерноорієнтованих регуляторних заходів на різних ієрархічних рівнях.

Аналіз останніх досліджень та публікацій. Дослідженню проблематики зовнішньої трудової міграції присвячені роботи багатьох науковців, зокрема: С. Гринкевич, Б. Кузьменка, О, Кваші, К. Ніколаєць, У. Садової, А. Тімофєєва, К. Шиманської та ін. Однак, незважаючи на значну кількість наукових публікацій в цій сфері, формування ефективної системи управлінських заходів з врахуванням гендерних особливостей трудової міграції не набуло широкого поширення в 
практичній діяльності органів державної влади різних рівнів. Відтак, дослідження гендерних аспектів міграційних намірів населення України $€$ актуальним науковим завданням.

Метою роботи є соціологічне дослідження міграційних настроїв жінок та чоловіків транскордонних регіонів України.

Виклад основного матеріалу. Аналізуючи гендерні аспекти профілю української міграції можна відмітити, що довгострокові трудові мігранти чоловічої статі переважають у віковій групі 30-44 років (50\% чоловіків / 36\% жінок), а трудових мігрантів-жінок більше в категорії 45-65 років (47\% жінок / 28\% чоловіків). У молодшій віковій групі 18-29 років кількість чоловіків / жінок більш збалансована (17\% / 22\%). Разом з тим між чоловіками й жінками існує чіткий поділ праці. Чоловіки в основному зайняті на будівництві, виробництві і в галузі транспорту, тоді як жінки зайняті в основному в догляді на дому та в готельно-ресторанному бізнесі. Молодші жінки більше працюють у готельно-ресторанному бізнесі, а старші жінки надають послуги догляду на дому. Будівництву надають перевагу багато молодих українських трудових мігрантів чоловічої статі. Середня різниця в особистому рівні доходів між чоловіками й жінками становить $5 \%$ на користь довгострокових трудових мігрантів чоловічої статі. При розгляді двох основних напрямків міграції можна побачити, що чоловіки заробляють в середньому на $22 \%$ більше в країнах СНД (1 456 доларів США проти 1198 доларів США серед жінок), тоді як у країнах ЄС в цілому панує паритет між особистими доходами чоловіків і жінок [4].

Для дослідження особливостей міграційних настроїв жінок та чоловіків транскордонних регіонів України авторами впродовж квітня-травня 2019 року було проведено соціологічне опитування осіб віком від 18 років Рівненської та Волинської областей. За отриманими результатами найперше слід відмітити, що близько $5 \%$ респондентів обох статей вже мали досвід роботи в інших країнах. При цьому основні джерела отримання інформації про можливості працевлаштування за кордоном для чоловіків і жінок були однаковими. Однак використання соціальних мереж $є$ більш традиційним для чоловічої аудиторії, в той час як розповіді родичів та друзів переважають в жіночому товаристві (рис. 1). 


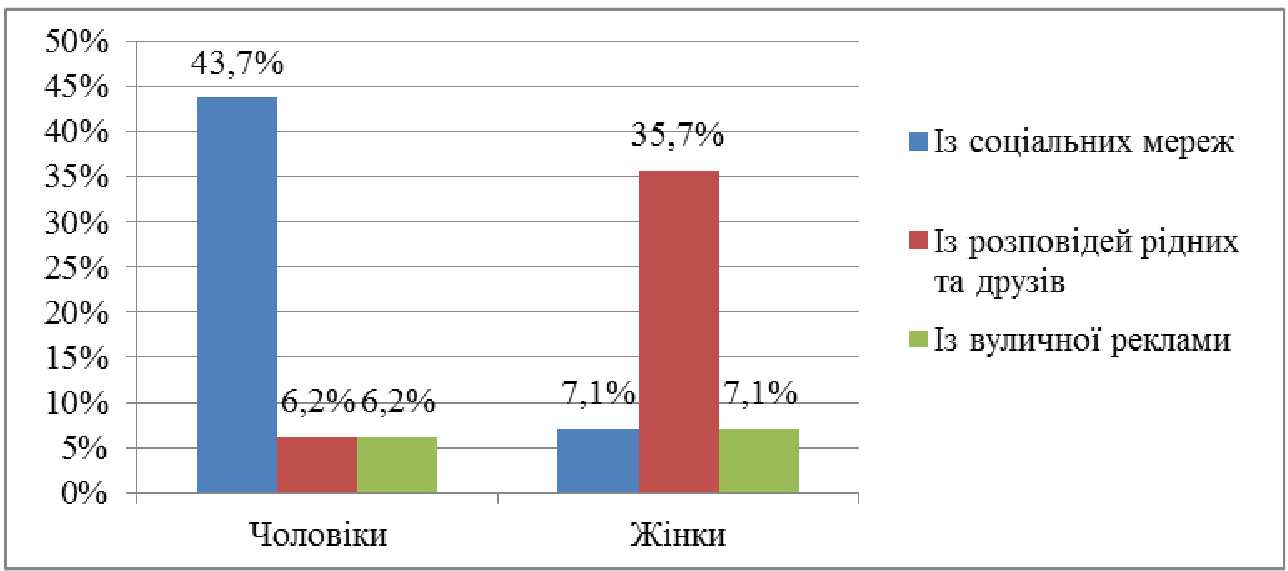

Рис. 1. Інформаційні джерела щодо працевлаштування за кордоном Джерело: складено авторами

Щодо бажання в майбутньому працювати за кордоном, то його виявили $37,5 \%$ чоловіків та 40,4\% жінок (рис. 2). Водночас тільки третина жіночної половини опитаних та кожен четвертий респондент чоловічої статі в якості місця своєї роботи бачать тільки Україну. Водночас значна частина респондентів на даний момент не визначились $з$ відповіддю на задане питання. Саме на цю категорію населення повинні бути направлені різного роду регуляторні заходи органів державної влади різних рівнів для того, аби загітувати розвивати саме свою країну, працюючи на вітчизняних підприємствах або створивши власну справу.

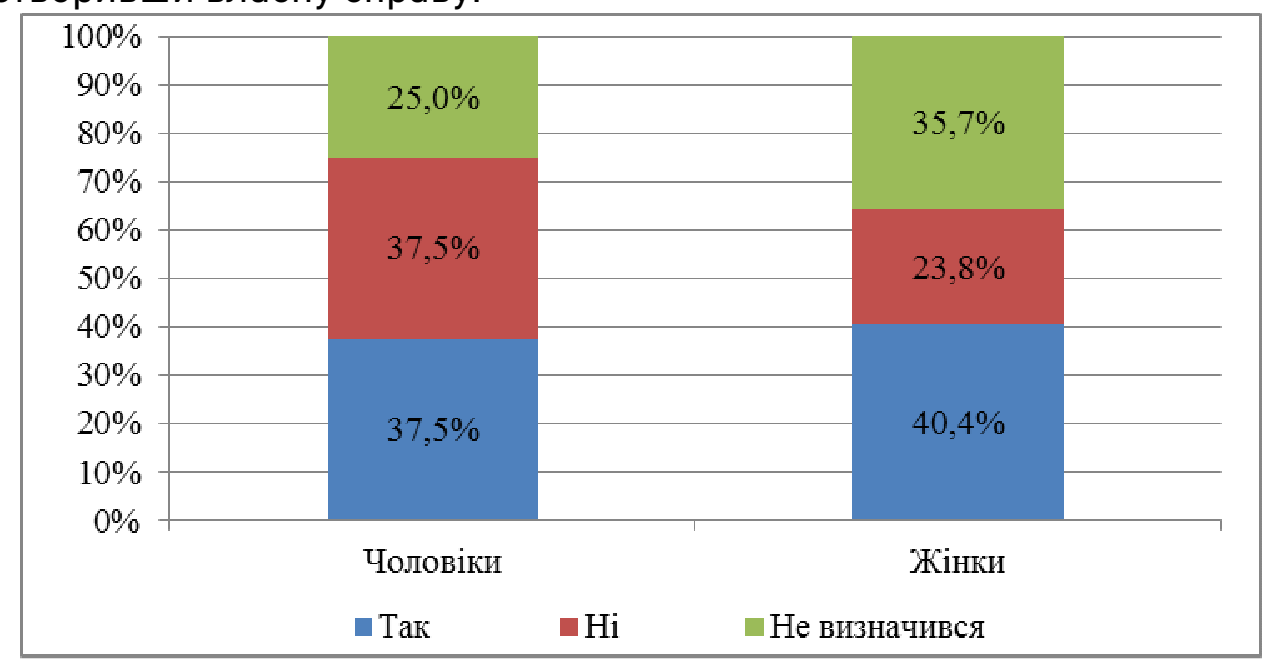

Рис. 2. Відповіді на питання «Чи хотіли б Ви працювати за кордоном?» Джерело: складено авторами

Найбільш популярною країною для еміграції $€$ США: третина опитаних жінок та майже половина чоловіків обрали цю відповідь в 
своїх анкетах. Другу сходинку займає Німеччина з показником 19\% в межах чоловічої аудиторії та $12,5 \%$ в межах жіночої. Особливістю в результатах опитування я те, що кожна десята жінка обрала Польщу як ймовірну країну для свого працевлаштування. Водночас жоден представник чоловічої статі не бачить цю країну як свого майбутнього роботодавця. 3 поміж інших країн респонденти називали Нідерланди, Російську Федерацію, Чехію, Канаду.

Варто відмітити, що основною причиною вибору саме цих країн для трудової міграції $€$ той фактор, що респондентам вони подобаються, імпонує стиль життя жителів, рівень загального добробуту (рис. 3).

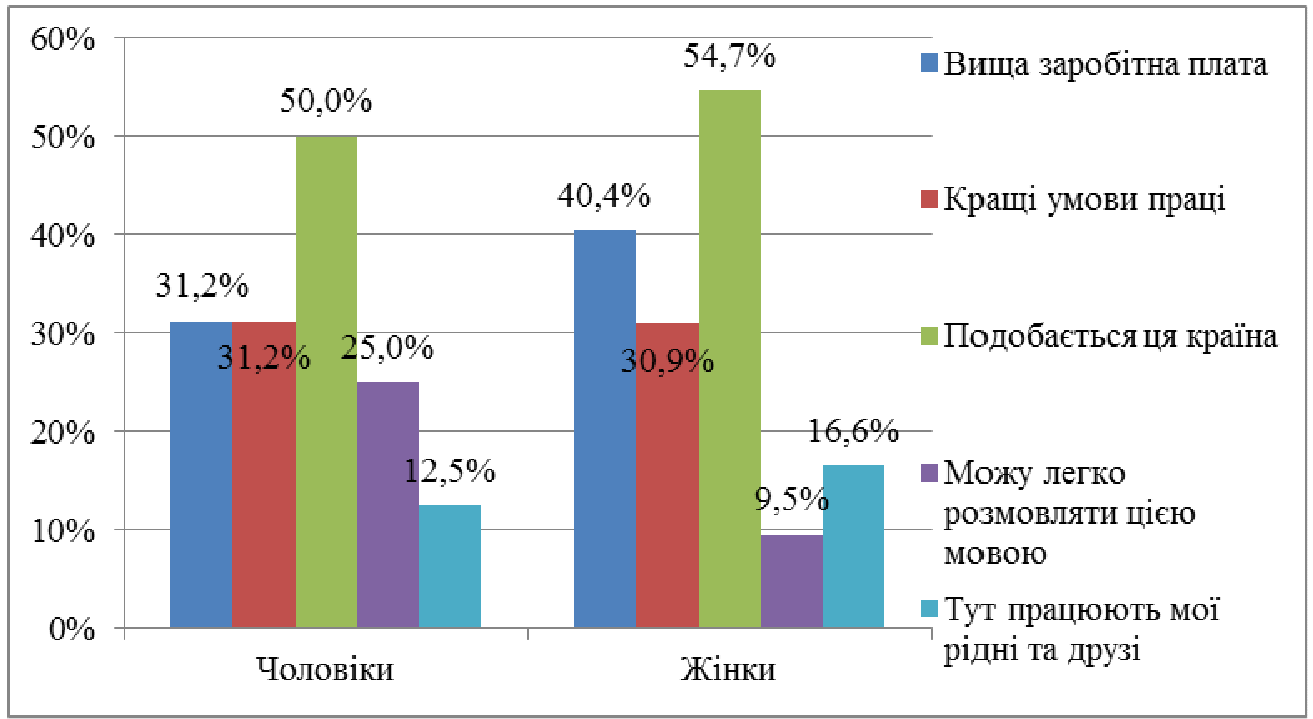

Рис. 3. Фактори вибору країни для трудової міграції

Джерело: складено авторами

Друге місце займає вищий рівень оплати праці на робочих місцях в обраних країнах. При цьому даний фактор є більш важливий для жінок, чим для чоловіків. Кращі умови праці замають третю позицію за важливістю як для чоловіків, так і для жінок. Що стосується рівня володіння іноземною мовою тієї країни, яка є пріоритетною для трудової міграції, то для чоловічої половини респондентів ця причина $є$ більш важливою в порівнянні з жіночою: $25 \%$ та 9,5\% відповідHO.

Позитивним елементом отриманих результатів $€$ те, що переважна більшість респондентів обох статей обирають короткотермінову трудову міграцію - не більше 3 місяців (рис. 4). Варто зауважити, що такий термін є оптимальним для половини чоловіків та третини жінок. 


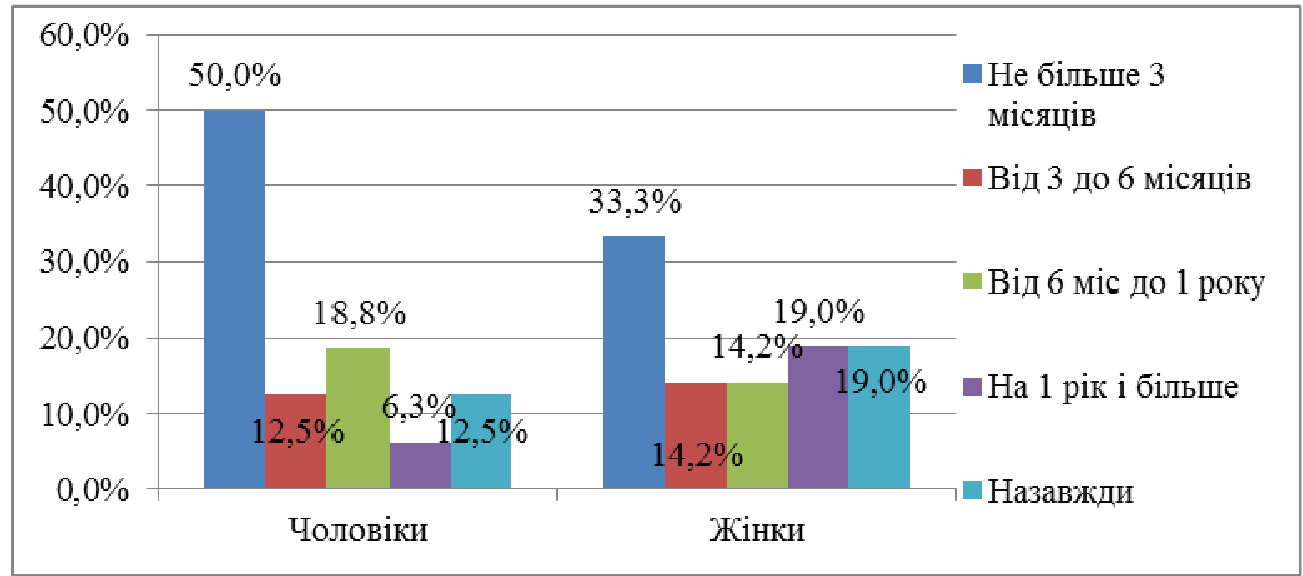

Рис. 4. Відповіді на питання «На який термін Ви б погодилися поїхати працювати за кордон?»

Джерело: складено авторами

Щодо інших запропонованих в анкеті варіантів відповідей, то думки опитаних різнились. Так, майже кожен п'ятий чоловік волів би працювати за кордоном терміном від 6 місяців до 1 року. Водночас, цей варіант обрали тільки 14,2\% жінок. Разом з тим результати опитування дозволяють стверджувати, що для жіночої категорії населення більш пріоритетною $€$ довготермінова трудова міграція. Зокрема, по 19\% респондентів відповіли, що хотіли б поїхати працювати за кордон впродовж одного року і більше та назавжди.

Найбільш важливим чинником, який змушує/змусив би шукати роботу за кордоном $€$ низький рівень оплати праці в нашій країні: ця причина очолює рейтинг у відповідях як чоловіків, так і жінок (рис. 4).

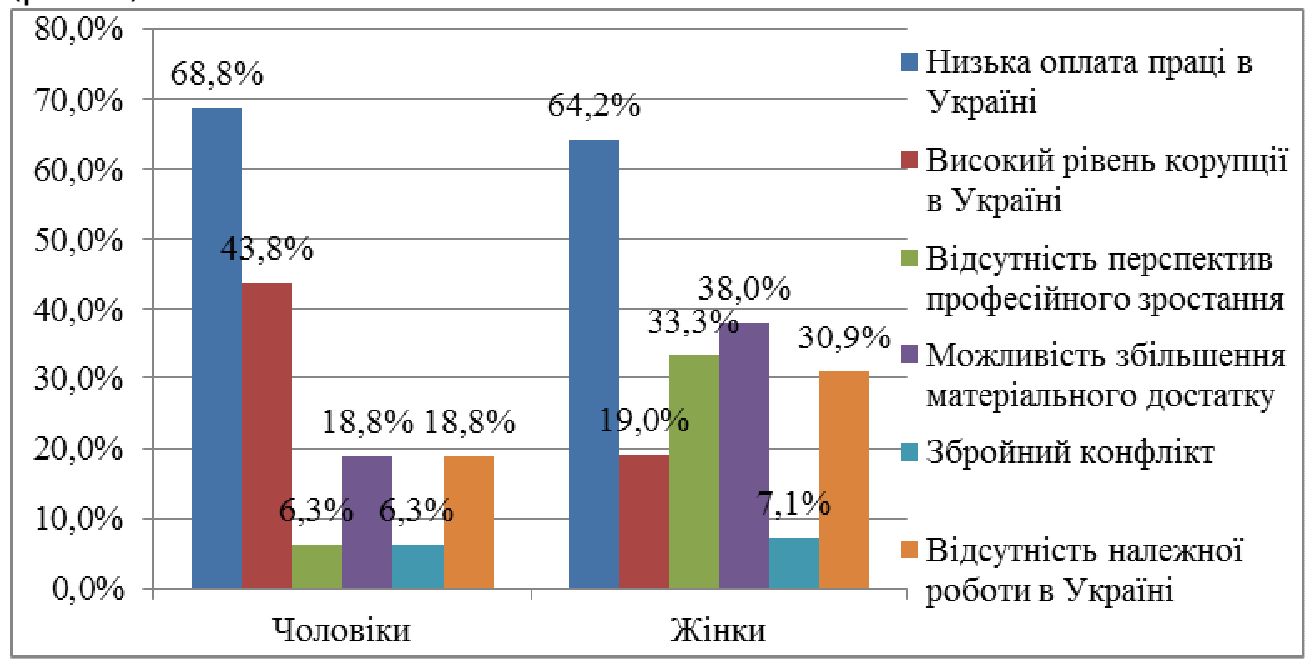

Рис. 5. Основні причини, які змушують/змусили б шукати роботу за кордоном

Джерело: складено авторами 
Однак пріоритет інших чинників значно різниться залежно від гендерної ознаки. Для жінок на другому місці $€$ можливість збільшення свого матеріального достатку (38\%), на третьому - відсутність перспектив професійного зростання (30,9\%). Водночас майже для $44 \%$ чоловіків $є$ більш важливим наявність високого рівня корупції на всіх ієрархічних рівнях в Україні.

Висновки. Результати проведеного дослідження дозволяють зробити висновки, що міграційні наміри чоловіків і жінок транскордонних регіонів України мають суттєві відмінності. За таких умов необхідно розробляти та впроваджувати гендерно-орієнтовані заходи, які дозволять оптимізувати потоки зовнішньої трудової міграції з України, гарантувати рівні права і можливості та однакове ставлення як до жінок, так і до чоловіків.

1. Українці за кордоном: чи зменшиться кількість трудових мігрантів в 2019 році / Міністерство соціальної політики України. URL: https://www.msp.gov.ua/news/16528.html (дата звернення: 15.03.2019). 2. Bloomberg оприлюднило причини трудової міграції з України - інфографіка URL: https://ua.news/ua/bloomberg-oprylyudnylo-prychyny-trudovoyimigratsiyi-z-ukrayiny-infografika/ (дата звернення: 15.03.2019). 3. Шиманська К. В. Гендерна структура української еміграції: сучасні тенденції, трансформації та соціально-економічні наслідки. Науковий вісник Ужгородського національного університету. 2017. Випуск 11. С. 184-188. 4. Міграція як чинник розвитку в Україні: Дослідження фінансових надходжень, пов'язаних з міграцією, та їх впливу на розвиток в Україні / Міжнародна організація 3 міграції, Представництво в Україні. URL: http://iom.org.ua/sites/default/files/mom_migraciya_yak_chynnyk_rozvytku_ v_ukrayini.pdf (дата звернення: 15.03.2019).

\section{REFERENCES:}

1. Ukraintsi za kordonom: chy zmenshytsia kilkist trudovykh mihrantiv v 2019 rotsi / Ministerstvo sotsialnoi polityky Ukrainy. URL: https://www.msp.gov.ua/news/16528.html (data zvernennia: 15.03.2019). 2. Bloomberg opryliudnylo prychyny trudovoi mihratsii z Ukrainy - infohrafika URL: $\quad$ https://ua.news/ua/bloomberg-oprylyudnylo-prychyny-trudovoyimigratsiyi-z-ukrayiny-infografika/ (data zvernennia: 15.03.2019). 3. Shymanska K. V. Henderna struktura ukrainskoi emihratsii: suchasni tendentsii, transformatsii ta sotsialno-ekonomichni naslidky. Naukovyi visnyk Uzhhorodskoho natsionalnoho universytetu. 2017. Vypusk 11. S. 184-188. 4. Mihratsiia yak chynnyk rozvytku $\vee$ Ukraini: Doslidzhennia finansovykh nadkhodzhen, poviazanykh z mihratsiieiu, ta yikh vplyvu na rozvytok v Ukraini / Mizhnarodna orhanizatsiia $z$ mihratsii, Predstavnytstvo $v$ Ukraini. URL: http://iom.org.ua/sites/default/files/mom_migraciya_yak_chynnyk_rozvytku_ 
Oliinyk 0. 0., Candidate of Economics (Ph.D.), Associate Professor, Pozharskyi D. S., Senior Student, Torianyk T. V., Senior Student (National University of Water and Environmental Engineering, Rivne)

\section{MIGRATION FOCUS OF THE POPULATION OF UKRAINIAN CROSS-BORDER REGIONS: GENDER ASPECTS}

The paper investigates the migratory sentiments of the population of cross-border regions of Ukraine. The study has revealed that $37.5 \%$ of the polled men and $\mathbf{4 0 . 4 \%}$ of women were willing to work abroad in the future. At the same time, as little as one third of female respondents and every fourth male respondent view Ukraine as an only place of their employment. The United States is the most desired country for potential migrants: one third of the women surveyed and almost half of the men chose this answer in their questionnaires. The foremost reason for choosing particular countries for labour migration is the fact that the respondents like their overall image, their lifestyle, and the level of general well-being. The second motive is higher wages at workplaces in selected countries. It is worth noting that this factor is more important for women than for men. The best conditions of work is the third parameter in order of importance for both men and women. The vast majority of the respondents of both sexes choose short-term labour migration, i.e. no more than $\mathbf{3}$ months. Low wages in our country appear to be the most critical factor, which compels / can possibly compel people to find work abroad.

Furthermore, this is the reason that leads the list of responses for both men and women. However, the priority of the other factors varies considerably depending on gender. For women, the second ranking has the opportunity to increase its material wealth (38\%), the third reason is the lack of prospects for professional growth $(\mathbf{3 0 . 9 \% )}$. Whereas almost $44 \%$ of men are more sensitive to the high level of corruption at all hierarchical levels in Ukraine. Under these conditions, it is truly a necessity to develop and implement genderbased measures that will optimise flows of foreign labour migration from Ukraine, as well as guarantee equal rights and opportunities for women and men.

Keywords: gender, migration, employment, wages, working conditions, population. 
Олейник Е. А., к.э.н., доцент, Пожарский Д. С., студент,

Торяник Т. В., студентка (Национальный университет водного хозяйства и природопользования, г. Ровно)

\section{МИГРАЦИОННЫЕ ОРИЕНТИРЫ НАСЕЛЕНИЯ ПРИГРАНИЧНЫХ РЕГИОНОВ УКРАИНЫ: ГЕНДЕРНЫЙ АСПЕКТ}

В статье исследованы миграционные настроения населения приграничных регионов Украины. Проанализированы факторы выбора мужчинами и женщинами страны для трудовой миграции, желаемые страны для трудоустройства за рубежом, срок пребывания. Определены основные причины, которые заставляют / заставили искать работу за рубежом.

Ключевые слова: гендер, миграция, трудоустройство, оплата труда, условия труда, населения. 